\title{
EFEKTIVITAS KEBIJAKAN PEMBELAJARAN DARING PADA MASA PANDEMI COVID-19 DI SMPN 2 SUKAMULYA KABUPATEN TANGERANG
}

\author{
Ika Ismayanti \\ Institut Pemerintahan Dalam Negeri (IPDN), Jatinangor \\ Email: ika.ismayanti@gmail.com
}

\begin{abstract}
Abstrak
Penelitian ini bertujuan untuk menganalisis efektivitas pembelajaran daring selama masa pandemi di SMPN Sukamulya Kabupaten Tangerang, dan menemukan strategi yang sesuai agar dapat dilakukan oleh pemerintah daerah Kabupaten Tangerang dalam implementasi pembelajaran secara Daring. Metode yang dipergunakan untuk penelitian ini adalah kualitatif deskriptif. Sumber data dalam penelitian ini bersumber dari informan yang bersentuhan langsung dengan kebijakan yang diterapkan. Hasil penelitian menunjukkan bahwa efektivitas kebijakan pembelajaran daring pada masa pandemi Covid-19 di SMPN 2 Sukamulya dipengaruhi oleh berbagai factor, diantaranya ketersediaannya jaringan internet, kompetensi guru, supervisi, motivasi belajar bagi siswa, bantuan khusus untuk kuota internet, kelayakan sekolah untuk menjalankan kebijakan pembelajaran daring, peraturan untuk mengatur keterlasanaan pembelajaran pada ruang kelas virtual, serta kelayakan penggunaan metode pembelajaran daring menurut guru dan orang tua siswa.
\end{abstract}

Kata Kunci: Efektivitas, Kebijakan, Pembelajaran Daring, Pandemi Covid-19.

\section{Abstract}

This study aims to analyze the effectiveness of online learning during the pandemic at SMPN Sukamulya, Tangerang Regency, and find appropriate strategies so that the Tangerang Regency local government can implement online learning. The method used for this research is descriptive qualitative. The source of data in this study comes from informants who are in direct contact with the policies implemented. The results showed that the effectiveness of online learning policies during the Covid-19 pandemic at SMPN 2 Sukamulya, was influenced by various factors, including the availability of internet networks, teacher competence, supervision, learning motivation for students, special assistance for internet quotas, school eligibility to run online learning policies, regulations to regulate the continuity of learning in virtual classrooms, and the feasibility of using online learning methods according to teachers and parents.

Keywords: Effectiveness, Policy, Online Learning, Covid-19 Pandemic.

\section{A. PENDAHULUAN}

Pandemi virus Covid-19, memaksa Indonesia memberlakukan sistem Pembatasan Sosial Berskala Besar (PSBB) guna menekan angka penularan virus. Efek yang ditimbulkan dari keadaan pandemi ini proses belajar mengajar di sekolah akhirnya mengalami titik buta, Pemerintah pusat melalui kementerian pendidikan mencoba mencari solusi untuk permasalahan pendidikan saat ini, mengingat negara wajib memberikan layanan pendidikan kepada seluruh warga negara dalam keadaan apapun. Menteri Pendidikan dan Kebudayaan 
(Mendikbud) Nadiem Anwar Makarim menerbitkan Surat Edaran Nomor 4 Tahun 2020 tentang Pelaksanaan Pendidikan Dalam Masa Darurat Coronavirus Disease (Covid-19).

Pemerintah Kabupaten Tangerang mengeluarkan Peraturan Bupati Tangerang Nomor 24 Tahun 2020 tentang Perubahan Atas Peraturan Bupati Nomor 20 Tahun 2020 tentang Pedoman PSBB dalam Percepatan Penanganan Corona Virus Disease 2019 (Covid-19). Sedangkan terkait waktu pelaksanaan PSBB di Kabupaten Tangeran, diatur dalam keputusan Bupati Tangerang Nomor 360/Kep.426-Huk/2020 tentang Penerapan Jangka Waktu Perpanjangan Pelaksanaan PSBB dalam Percepatan Penanganan Covid-19.

Dinas Pendidikan Kabupaten Tangerang mengeluarkan Surat Edaran tentang Implementasi Kebijakan Pendidikan Dalam Masa Darurat Penyebaran Corona Virus Disease (Covid-19) pada Satuan Pendidikan di Kabupaten Tangerang pada Kamis (26/03/20). Surat edaran yang tertuang dalam Nomor: 440/1211-Disdik/III/2020 tertanggal 26 Maret 2020 ini berlaku untuk SD/MI/Sederajat Negeri dan Swasta se-Kabupaten Tangerang, SMP/MTs/Sederajat Negeri dan Swasta se-Kabupaten Tangerang, PAUD/TK/KB/PKBM dan Kursus se-Kabupaten Tangerang. Surat edaran tersebut memuat kebijakan-kebijakan pengelolaan pendidikan di Kabupaten Tangerang sebagai berikut:

1. Mengingat Status Tanggap Darurat Bencana Wabah Penyakit Akibat Virus Corona Disease (Covid-19) di Kabupaten Tangerang diperpanjang sampai dengan tanggal 23 Mei 2020, maka proses belajar peserta didik dilaksanakan di rumah melalui pembelajaran daring/jarak jauh untuk memberikan pengalaman belajar yang bermakna bagi peserta didik diperpanjang sampai dengan tanggal 23 Mei 2020;

2. Untuk Pelaksanaan Ujian Nasional (UN) bagi jenjang pendidikan SD/MI/SMP/MTs/Sederajat Negeri dan Swasta serta PKBM Tahun 2020 ditiadakaan/dibatalkan, dan keikutsertaan UN tidak menjadi syarat kelulusan/seleksi masuk jenjang pendidikan yang lebih tinggi;

3. Memastikan proses Ujian Sekolah dan Ujian Akhir Sekolah untuk kenaikan kelas tidak diperkenankan dilaksanakan dalam bentuk test yang mengumpulkan peserta didik namun dapat dilakukan dalam bentuk portofolio nilai rapor dan prestasi yang diperoleh sebelumnya, penugasan, tes daring, dan/atau bentuk asesmen jarak jauh lainnya, yang dirancang untuk mendorong aktivitas belajar yang bermakna, dan tidak perlu mengukur ketuntasan capaian kurikulum secara menyeluruh;

4. Kelulusan jenjang SD/MI/sederajat ditentukan berdasarkan nilai lima semester terakhir (kelas 4, kelas 5, dan kelas 6 semester gasal). Nilai semester genap kelas 6 dapat digunakan sebagai tambahan nilai kelulusan sedangkan kelulusan jenjang SMP/MTs/sederajat ditentukan berdasarkan nilai 5 semester terakhir. Nilai semester genap kelas 9 dapat digunakan sebagai tambahan nilai kelulusan;

5. Menunda/menghentikan mengumpulkan/melibatkan/mengundang banyak orang (khususnya peserta didik antar satuan pendidikan) atau kegiatan di lingkungan luar satuan pendidikan yang mengundang banyak orang (berkemah, studi wisata dan sebagainya) serta menghindari bepergian ke tempat keramaian sampai permasalahan Virus Covid-19 dinyatakan mereda;

6. Mengalokasikan Dana Bantuan Operasional Sekolah atau Bantuan Operasional Pendidikan untuk membiayai keperluan dalam pencegahan Covid-19 di lingkungan satuan pendidikan seperti pengadaan dan penyediaan alat-alat kebersihan, hand 
sanitizer, disinfectant dan masker kesehatan serta membiayai pembelajaran daring/jarak jauh.

Beberapa kendala yang muncul pada proses pembelajaran daring, berikut adalah identifikasi yang bisa diuraikan:

1. Masih rendahnya tingkat ekonomi di Kabupaten Tangerang dengan luas wilayah $959,61 \mathrm{~km}^{2}$.

2. Belum efektifnya pembelajaran daring di Kabupaten Tangerang jika dikaitkan dengan hasil nilai siswa.

3. Kurangnya perhatian orangtua siswa terhadap sistem pendidikkan daring dikarenakan aktifitas jam yang bersamaan dengan aktifitas kantor/kerja.

4. Kurangnya keahlian/skill orangtua dalam membimbing anak terkait bidang akademik.

5. Belum adanya solusi dari permasalahan pembelajaran daring di SMPN 2 Sukamulya Kabupaten Tangerang.

Sebagai daerah penyangga ibu kota, Kabupaten Tangerang dan Kecamatan Sukamulya terdapat 13.108 penduduk yang memiliki masalah ekonomi, dan saat ini dalam masa pandemi Covid-19, memiliki daya tarik tersendiri bagi penyusun untuk melakukan penelitian dan semestinya penelitian dilakukan secara fokus dan terarah, maka untuk itu penulis melakukan pembatasan penelitian, yaitu efektivitas pembelajaran daring selama pandemi Covid-19 di SMPN 2 Sukamulya Kabupaten Tangerang.

Ameli, dkk. (2020), melakukan penelitian dengan judul Analisis Keefektifan Pembelajaran Online di Masa Pandemi Covid-19 melalui metode penelitian kualitatif eksploratif. Sedangkan Mustakim (2020), SMA Negeri 1 Wajo, Sulawesi Selatan melakukan penelitian berjudul Efektivitas Pembelajaran Daring Menggunakan Media Online Selama Pandemi Covid-19 Pada Mata Pelajaran Matematika, sedangkan Kurniasari, dkk. (2020). Pendidikan Guru Sekolah Dasar, Fakultas Keguruan dan Ilmu Pendidikan Universitas Muhammadiyah Surabaya melakukan penelitian berjudul Analisis Efektivitas Pelaksanaan Belajar Dari Rumah (Bdr) Selama Pandemi Covid-19. Dari ketiga peneliti tersebut di atas masih belum ada yang melakukan riset terhadap efektifitas kebijakan pembelajaran daring sehingga mereka fokus kepada pembelajaran daringnya. Sedangkan komponen yang berpengaruh salah satunya adalah kebijakan itu sendiri William N. Dunn menyatakan bahwa tujuan analisis kebijakan adalah untuk memperbaiki kebijakan dengan cara menciptakan, secara kritis menilai, dan mengkomunikasikan pengetahuan yang relevan dengan kebijakan. Tetapi perbaikan kebijakan mensyaratkan digunakannya pengetahuan tersebut oleh pengambil kebijakan, suatu proses yang rumit yang terbentuk melalui pertemuan antara tiga dimensi utama pemanfaatan pengetahuan

Tujuan penelitian ini adalah untuk menganalisis efektivitas pembelajaran selama kebijakan belajar online pada masa pandemi di SMPN 2 Sukamulya Kabupaten Tangerang, dan nenemukan strategi yang sesuai agar dapat dilakukan oleh Pemerintah Daerah Kabupaten Tangerang dalam implementasi pembelajaran secara daring.

\section{B. TINJAUAN PUSTAKA}

Di dalam Undang-undang 23 Tahun 2014 Bidang pendidikan masuk ke dalam klasifikasi konkuren, wajib dan berkaitan dengan pelayanan dasar maka pada masa pandemi 
ini diperlukan perhatian khusus. Dengan diberlakukannya peraturan turunan yang mengatur pembatasan kegiatan belajar secara tatap muka langsung selama masa pandemi Covid-19 maka diterapkannya belajar secara daring. Pada pelaksanaannya baik belajar secara jarak jauh secara online maupun belajar tatap muka langsung (offline) tetap harus memperhatikan tercapainya tujuan pembelajaran. Merujuk pada pendapat Robert F. Mager (dalam Uno, 2008) tujuan pembelajaran adalah perilaku yang hendak dicapai atau yang dapat dikerjakan oleh siswa pada kondisi dan tingkat kompetensi tertentu. Kemp dan Kapel (Uno, 2008), menyebutkan bahwa tujuan pembelajaran adalah suatu pernyataan spesifik yang dinyatakan dalam perilaku atau penampilan yang diwujudkan dalam bentuk tulisan untuk menggambarkan hasil belajar yang diharapkan. Henry Ellington dalam Hamzah B. Uno (2008) menyatakan bahwa tujuan pembelajaran adalah pernyataan yang diharapkan dapat dicapai sebagai hasil belajar. Sementara itu, Hamalik (2005) menyebutkan bahwa tujuan pembelajaran adalah suatu deskripsi mengenai tingkah laku yang diharapkan tercapai oleh siswa setelah berlangsung pembelajaran

Efektivitas suatu program bisa diukur dari beberapa elemen. Elemen tersebutdapat berasal dari pihak intern pembuat program ataupun dari para pelaksana program serta sasaran program. Dicson dan Wetherbe (dalam Samsudin (2014) menyatakan bahwa ada beberapa elemen penting lainnya dalam aparatur bekerja pada suatu organisasi, yaitu: kualitas aparatur, kompetensi administrator, disiplin, sarana dan prasarana dan pengawasan sebagai berikut:

1. Kualitas aparatur; kualitas dalam arti luas yaitu sesuatu yang dapat disempurnakan. Dalam arti sempit, istilah kualitas sumber daya manusia pada dasarnya adalah tingkat: "Pengetahuan", "kemampuan", dan "kemauan" yang dapat diajukan oleh sumber daya manusia. Kualitas aparatur sangat menentukan efektif atau tidaknya suatu program karena aparaturlah yang akan merumuskan tujuan dan menjalankan program tersebut.

2. Kompetensi administrator, kompetensi adalah suatu tugas yang memadai, atau pemilikan pengetahuan, keterampilan dan kemampuan yang dituntut oleh jabatan seseorang. Kemampuan merupakan dorongan yang dimiliki individu untuk menyelesaikan sebuah tugas dan tanggung jawab. Rivai (2004) menjelaskan bahwa kemampuan adalah kapasitas individu untuk melaksanakan berbagai tugas dalam pekerjaan tertentu.

Sebagai upaya untuk mencegah pandemi Covid-19, pemerintah mengeluarkan kebijakan agar sekolah-sekolah meminta siswanya untuk belajar di rumah. Mulai 16 Maret 2020 sekolah menerapkan metode pembelajaran siswa secara daring. Pemerintah daerah memutuskan untuk meliburkan sekolah dan melaksanakan pembelajaran daring akan tetapi tidak seluruh sekolah menerapkan kebijakan ini. Sebab mengingat letak dan geografis yang tidak dapat mendukung metode pembelajaran daring. Sistem pembelajaran daring (dalam jaringan) merupakan sistem pembelajaran tanpa tatap muka secara langsung antara guru dan siswa tetapi dilakukan melalui online yang menggunakan jaringan internet. Guru harus memastikan kegiatan belajar mengajar tetap berjalan, meskipun siswa berada di rumah. Solusinya, guru dituntut dapat mendesain media pembelajaran sebagai inovasi dengan memanfaatkan media daring (online).

Hal ini sesuai dengan Menteri Pendidikan dan Kebudayaan Republik Indonesia terkait Surat Edaran Nomor 4 Tahun 2020 tentang Pelaksanaan Kebijakan Pendidikan dalam Masa Darurat Penyebaran Corona Virus Disease (Covid-19). Sistem pembelajaran 
dilaksanakan melalui perangkat personal computer (PC) atau laptop yang terhubung dengan koneksi jaringan internet. Guru dapat melakukan pembelajaran bersama di waktu yang sama menggunakan grup di media sosial seperti WhatsApp (WA), telegram, instagram, aplikasi zoom ataupun media lainnya sebagai media pembelajaran. Dengan demikian, guru dapat memastikan siswa mengikuti pembelajaran dalam waktu yang bersamaan, meskipun di tempat yang berbeda.

Penggunaan metode pembelajaran daring (dalam jaringan)/online di SMPN 2 Sukamulya Kabupaten Tangerang yang mana kondisi social dan infrastruktur jaringan telekomunikasi/internet masih belum bisa dinikmati secara merata oleh masyarakat di Kecamatan Sukamulya Kabupaten Tangerang. Seberapakah efektifkah metode pembelajaran ini bisa diterapkan, mengingat proses pembelajaran tidak bisa terlepas dari kontrol guru dan orang tua terhadap aktifitas anak/peserta didiknya. Media online memiliki daya tarik tersendiri akan tetapi memiliki beberapa nilai yang negatif. Untuk proses pembelajaran daring peserta didik memerlukan perangkat tersendiri. Perangkat ini bisa berupa personal komputer, laptop maupun gadget seperti tablet atau handphone yang sudah bisa terhubung ke internet. Perangkat-perangkat tersebut haruslah memiliki spesifikasi tersendiri agar bisa menjalankan program atau aplikasi yang dipergunakan dalam kegiatan pembelajaran daring, dan biasanya proses pembelajaran daring seringkali menggunakan aplikasi berbasis video call. Untuk mendukung aplikasi seperti itu perangkat pendukung seperti jaringan internet dan hardware dari gadget haruslah tinggi, dengan kata lain metode pembelajaran ini memerlukan biaya yang besar baik yang harus dikeluarkan oleh sekolah ataupun orang tua siswa, dan hal ini yang harus menjadi tolak ukur untuk keberlangsungan metode pembelajaran daring. Garis besar kerangka berpikir peneliti dapat terlihat pada gambar di bawah ini.

\section{METODE PENELITIAN}

Penelitian ini menggunakan desain penelitian kualitatif dengan metode deskriptif (Sugiyono, 2009:1). Dalam penelitian ini, penulis menggunakan teknik pengumpulan data berupa teknik pengamatan langsung (observasi langsung), teknik wawancara mendalam, dan teknik dokumentasi. Miles \& Huberman dalam Sugiyono (2009:246) menyatakan bahwa "aktivitas dalam analisis data, yaitu data reduction, data display, dan conclusion/drawing/verification". Dalam penelitian ini, peneliti menggunakan teknis analisis data berdasarkan pendapat Miles dan Huberman tersebut, dimana peneliti akan mengumpulkan data yang dibutuhkan melalui wawancara dan dokumentasi. Data tersebut selanjutnya diseleksi agar pembahasan menjadi fokus sesuai dengan permasalahan penelitian. Selanjutnya, data yang telah diseleksi tersebut disajikan dalam bentuk deskripsi atau narasi yang sistematis agar mudah dipahami. Langkah terakhir yaitu peneliti menyimpulkan hasil penelitian berdasarkan uraian hasil penelitian yang telah disajikan.

\section{HASIL PENELITIAN DAN PEMBAHASAN}

\section{Efektivitas Pembelajaran Daring di Kabupaten Tangerang}

Kabupaten Tangerang adalah kabupaten yang berada di wilayah Tatar Pasundan, Provinsi Banten, Indonesia. Kabupaten ini terletak tepat di sebelah barat DKI Jakarta. Dengan luas wilayah $959,61 \mathrm{~km}^{2}$ atau $12,62 \%$ dari seluruh luas wilayah Provinsi Banten. Kabupaten Tangerang ini terbagi 29 kecamatan, 28 kelurahan dan 246 desa. 
Kepala Dinas Pendidikan Kabupaten Tangerang, Syaifullah mengatakan, Surat edaran ini untuk menindaklanjuti Surat Edaran Menteri Pendidikan dan Kebudayaan Republik Indonesia Nomor 4 Tahun 2020 tentang Pelaksanaan Kebijakan Pendidikan dalam Masa Darurat Penyebaran Coronavirus Disease (Covid-19), dan Keputusan Bupati Tangerang Nomor: 440/Kep.273-Huk/2020 tentang Tanggap Darurat Bencana Wabah Penyakit Akibat Virus Corona Disease (Covid-19) di Kabupaten Tangerang (Bidang IKP Diskominfo Kab Tangerang).

Demi terlaksananya proses penilaian dan pembelajaran secara Daring pada jenjang SMP di Kabupaten Tangerang maka pemerintah Kabupaten Tangerang menyiapkan program yaitu Daring dan Luring. Daring adalah proses pembelajaran menggunakan metode (dalam jaringan) menggunakan basis internet dan jaringan. Pelaksanaan penelitian evaluasi efektifitas pembelajaran daring di SMPN 2 Sukamulya Kabupaten Tangerang bertujuan untuk memberikan masukan kepada Dinas Pendidikan Kabupaten Tangerang agar proses pembelajaran daring kedepannya semakin efektif dan efisien sehingga pelayanan yang diterima oleh masyarakat lebih baik. Penelitian yang penulis lakukan berdasarkan kepada model indicator Efektivitas Dicson dan Wetherbe (dalam Samsudin (2014) yaitu:

a. Kualitas Aparatur

Kompetensi aparatur Negara dalam hal ini adalah tenaga pendidik/guru yang selaku ujung tombak dari pelaksana kebijakan pembelajaran daring merupakan komponen penunjang utama agar kebijakan tersebut dapat berjalan sesuai dengan arah kebijakan. Sedangkan yang menjadi indikator tercapainya dimensi kualitas aparatur negera adalah "aparatur berhasil melaksanakan kebijakan pembelajaran daring". Bapak Bupati selaku kepala daerah beliau sudah mencanangkan dari bulan Maret 2020 karena mengetahui kondisi daerahnya bervariatif tentang jaringan beliau mencanangkan selain ada Daring, selain ada Luring coba menggunakan Home Visit. Home visit itu tenaga pendidik datang ke rumah baik secara pribadi rumah peserta didik ataupun secara kelompok peserta didik yang kita temui satu rumah untuk 6-10 orang berkumpul di halamannya mereka mengajar. Lebih lanjut beliau berkata bahwa: Konsep pemerintah daerah dalam rangka peningkatan SDM tenaga pendidik, sekali lagi dari tahun 2012 kami selalu menyelenggarakan peningkatan kompetensi tenaga pendidik yang difasilitasi oleh LPMP, untuk meningkatkan mutu pendidik LPMP itu yang memfasilitasi

Berdasarkan informasi yang diungkapkan oleh informan ada beberapa poin krusial yang mana terdapat upaya yang dilakukan oleh Aparatur Negara, bupati Kabupaten Tangerang memiliki pengetahuan yang mendalam terhadap kondisi wilayahnya sehingga beliau memiliki kompetensi yang baik untuk menjalankan kebijakan pembelajaran daring. Sedangkan untuk Kepala Dinas Pendidikan Kabupaten Tangerang beliau memiliki kemampuan yang baik, meski pada masa pandemi ini beliau masih memikirkan bagaimana caranya untuk terus meningkatkan kemampuan tenaga pendidik melalui pendidikan dan pelatihan yang difasilitasi oleh LPMP (Lembaga Penjamin Mutu Pendidikan) Provinsi Banten. Sedangkan dari hasil pengamatan yang penulis lakukan di lapangan para aparatur Negara yang terkait dalam pembelajaran daring sudah memiliki kompetensi dalam melaksanakan kebijakan pembelajaran daring. Adanya upaya agar terlaksananya pembelajaran yang baik dan dapat dilaksanakan oleh seluruh Sekolah di Kabupaten Tangerang, Pemerintah Daerah Kabupaten Tangerang mengalokasikan dana untuk 
peningkatan kualitas jaringan.

b. Kompetensi Administrator

Tenaga pendidik merupakan peran utama sebab secara formal, guru adalah seorang pengajar di sekolah negeri ataupun swasta yang memiliki kemampuan berdasarkan latar belakang pendidikan formal minimal berstatus sarjana, dan telah memiliki ketetapan hukum yang sah sebagai guru berdasarkan undang-undang guru dan dosen yang berlaku di Indonesia

Pada dimensi kompetensi administrator ada pada poin Guru berhasil melaksanakan kebijakan pembelajaran dengan model pembelajaran daring. Berikut apa yang telah Kepala Dinas Pendidikan Kabupaten Tangerang ungkapkan: Komposisi tenaga pendidik secara struktural status ada ASN ada Non ASN, secara jenjang pendidikan SMA, DI, DII, DIII, S1, S2 bahkan ada yang S3. Ada yang "senior-senior" dalam jam kerja sudah tinggi tetapi dalam pengelolaan TIK mereka kurang begitu faham tetapi alhamdulillah semuanya berjalan lancar, karena mereka berkolaborasi dengan para tenaga pendidik yang ada di sekolah yang usianya lebih muda atau yang lebih mengerti TIK.

\section{c. Disiplin}

Disiplin adalah perasaan taat dan patuh terhadap suatu nilai atau peraturan yang telah ditetapkan dan juga sudah menjadi tanggung jawabnya untuk dilaksanakan dengan baik. Dengan disiplin siswa akan lebih mudah dalam memahami dan mencermati proses pembelajaran yang sedang berlangsung. Kemampuan memahami dan mencermati siswa akan sangat berpengaruh terhadap prestasi yang dicapai ke depannya. Disiplin diri merujuk pada pelatihan yang didapatkan seseorang untuk memenuhi tugas tertentu atau untuk mengadopsi pola perilaku tertentu, walaupun orang tersebut lebih senang melakukan hal yang lain. Sebagai contoh, seseorang mungkin saja tidak melakukan sesuatu yang menurutnya memuaskan dan menyenangkan dengan membelanjakan uangnya untuk sesuatu yang ia inginkan dan menyumbangkan uang tersebut kepada organisasi amal dengan pikiran bahwa hal tersebut lebih penting. Secara etimologi disiplin berasal dari bahasa Latin "disibel" yang berarti Pengikut. Seiring dengan perkembangan zaman, kata tersebut mengalami perubahan menjadi "disipline" yang artinya kepatuhan atau yang menyangkut tata tertib. Disiplin memerlukan integritas emosi dalam mewujudkan keadaan. Disiplin diri berawal dari hal-hal kecil, seperti misalnya bagi pelajar yang mampu membagi waktu untuk belajar, untuk bermain sehingga tak menimbulkan suatu pertabrakan kegiatan pada waktu yang sama. Disiplin diri juga bisa kita lihat dengan contoh sederhana yaitu dengan pelajar tersebut mengerjakan PR (pekerjaan rumah) dan dikumpulkan di sekolah tepat pada waktunya. Pada dimensi disiplin ini memiliki indikator "Siswa berhasil melaksanakan pembelajaran daring dengan disiplin"

\section{d. Sarana dan Prasarana}

Sarana dan prasarana merupakan hal yang utama terlebih untuk kebijakan pembelajaran daring tidak terlepas dari sarana dan prasarana yang ada. Sebagai sarana utama pembelajaran daring jaringan merupakan poin krusialnya sedangkan sebagai prasarana alat dan peralatan gadget pendukung menjadi peran penunjang lainnya. Pada lingkup sarana dan prasarana memiliki indikator capaian sebagai berikut "Guru, murid dan orang tua siswa puas terhadap Sarana dan prasarana yang diberikan oleh pemerintah Kabupaten Tangerang. "Kegiatan pemerintah Kabupaten Tangerang dalam bidang pendidikan tertuang dalam program unggulan bapak Bupati Tangerang sesuai dengan visi misi bapak bupati yaitu 
tangerang religius, tangerang cerdas, Tangerang sehat dan tangerang sejahtera. Di dalam progres tangerang religius dan cerdas itu menjadi satu kesatuan walaupun tangerang sehat juga ada di dunia pendidikan dan juga tangerang sejahtera. Kembali kepada tangerang cerdas bapak bupati tangerang progres dari tahun 2019-2020 progresnya meningkat dalam program kegiatan namun di 2020 agak terkendala program-program penyedia sarana fisik konstruksi terbatas dan terhambat. Karena adanya pandemi covid-19, dimana semua tahu bahwa akibat pandemi covid-19 anggaran direstrobusi hampir 50-75\% diarahkan dan dialihkan untuk penanganan covid-19 walaupun demikian masih ada sisa-sisa pekerjaan yang tetap dilaksanakan oleh Pemerintah Kabupaten Tangerang. Kita mengetahui kondisi sarana dan prasarana itu sebab Dinas Pendidikan Kabupaten Tangerang setiap tahun membuat profil pendidikan di Kabupaten Tangerang yang isinya adalah keberadaan tenaga pendidik, keberadaan mutu pendidikan dan juga keberadaan sarana dan prasarana. Setiap tahun terlihat progres untuk sarana prasarana 2019 jumlah sekolah tetap lembaga dan juga bangunannya kurang misalnya ada bangunan yang kurang 1000 di tahun 2020 akan berkurang dari 1000 menjadi 900 berarti 100 yang sudah dibangun itu selalu seperti itu. Termasuk kepada SDM (tenaga pendidik) khususnya tenaga honorer, walaupun sudah ada kebijakan Kementerian Pendidikan juga Kemenpan dilarang mengangkat tenaga pendidik honorer, sementara kita mencoba meningkatkan kesejahteraan dari mulai 2013 sampai sekarang selalu meningkat progres pendapatan tenaga pendidik dan yang sangat saya banggakan dari Bapak Bupati bagi kami para ASN di masa pandemi covid-19 honornya dipotong 5\% tapi bagi tenaga pendidik beliau "Bapak Bupati" bersikukuh tidak ada pemotongan, jadi mereka mendapatkan utuh dan full, walaupun dalam pelaksanaan tugasnya mereka tidak tatap muka tetapi di rumah tapi beliau berfikir bahwa walaupun mereka "tenaga pendidik" di rumah akan tetapi fikiran dan tetap memonitor, memotivasi dan mengarahkan anak didiknya untuk melaksanakan pembelajaran jarak jauh"

Sedangkan menurut guru bahwa sarana dan prasarana pendukung pembelajaran daring adalah tersedianya jaringan yang optimal dan ketersediaan gadget pendukung. Tidak jauh dari pendapat guru orang tua siswa juga berpandangan sama terhadap masalah sarana dan prasarana pendukung pembelajaran daring.

Berdasarkan pernyataan informan dari pengamatan peneliti di lapangan terlihat bahwa secara umum permasalahan sarana dan prasarana pemenuhan pembelajaran daring adalah ketersediaan jaringan yang memadai dan gadget yang mendukung untuk aplikasi daring yang dipilih. Kepemilikan gadget oleh peserta didik juga merupakan salah satu sarana yang dapat mendukung keterlaksanaan pembelajaran daring.

Dari hasil pengamatan yang penulis lakukan di lapangan secara keseluruhan sarana dan prasarana di SMPN 2 Sukamulya sudah bisa untuk melaksanakan kebijakan pembelajaran daring, SMPN 2 Sukamulya memiliki laboratorium komputer yang memadai beserta jaringan internet dengan kecepatan jaringannya baik. Seluruh guru sudah memiliki laptop dan gadget pendukung lainnya. Sehingga dalam proses persiapan bahan ajar serta penyampaian sudah bisa dilaksanakan. Sedangkan untuk wilayah dengan kondisi jaringan internetnya kurang baik/buruk sekolah memiliki kebijakan yaitu guru mengunjungi spot area tersebut ke rumah peserta didik untuk memberikan arahan dan bimbingannya.

e. Pengawasan

Untuk setiap kebijakan diperlukan pengawasan agar diketahui keterlaksanaan 
kebijakan tersebut. Apakah sudah sesuai dengan arah kebijakan atau tidak, permasalahan dan kendala apa saja yang ditemukan ketika menjalankan kebijakan tersebut sehingga dapat diketahui upaya apa yang bisa lakukan untuk mengantisipasinya. Pada dimensi pengawasan terdapat indikator capaian yaitu "Dinas Pendidikan Kabupaten Tangerang berhasil melakukan pengawasan terhadap berjalannya kebijakan pembelaran daring".

Di bawah ini terungkap melalui wawancara dengan Kepala Dinas Pendidikan Kabupaten Tangerang, bahwa: "Supervisi kita lakukan dengan pola tahapannya melalui para pengawas, dinas pendidikan memanggil para pengawas setiap dua bulan sekali di masa pandemi, kita akan evaluasi mereka dan kita tinggal menanyakan apa yang sudah dilakukan teman-teman sekolah dan pengawas sekolah memberikan laporan. Permasalahan di lapangan seperti apa, yang selama ini oleh pengawas sekolah sudah disikapi dengan bijak bagaimana, dan jika memang masih belum, dinas pendidikan akan menyikapi, jika tidak bisa maka dinas pendidikan beserta dinas teknis lainnya akan mengatasi, jika masih belum bisa maka dinas pendidikan akan menyikapi dengan pimpinan, baik DPRD maupun bapak Bupati”

Berdasarkan pernyataan informan dan pengamatan peneliti di lapangan terungkap bahwa setiap dua bulan sekali Dinas Pendidikan melakukan pemanggilan Pengawas Sekolah untuk menyampaikan kesulitan yang dihadapi oleh Sekolah, sehingga pemerintah daerah bisa menyikapi permasalahan yang ada.

Dari hasil pengamatan yang penulis lakukan di lapangan terlihat bahwa diperlukannya supervise secara komprehensip, terstruktur dan berkelanjutan mengingat metode pembelajaran daring ini merupakan metode baru yang diterapkan secara keseluruhan di Indonesia khususnya di SMPN 2 Sukamulya Kabupaten Tangerang sehingga apa dan seperti apa capaian yang diperoleh dapat diketahui secara cepat, tepat dan akurat sehingga rencana tindak lajut dapat segera disusun dan dilaksanakan agar perkembangan pendidikan di Kabupaten Tangerang dapat terus meningkat ke arah yang lebih baik lagi.

\section{Upaya Pemerintah Kabupaten Tangerang dalam Mengefektifkan Pembelajaran Daring}

Upaya yang dilakukan oleh pemerintah Kabupaten Tangerang dalam mengefektifkan pembelajaran daring adalah dengan membuat "e-learning system" ini sejalan dengan apa yang disampaikan oleh Kepala Dinas Pendidikan Kabupaten Tangerang bahwa sebenarnya Bupati Kabupaten Tangerang sudah mencanangkan e-learning system pada tahun 2019 bahkan konsep ini sudah disampaikan langsung kepada menteri pendidikan, dengan membuat "home school" dengan sistem pembelajaran ini murid tidak lagi berkerumun di sekolah dengan memberikan jadwal tatap muka. Dalam satu minggu siswa dapat mengikuti pembelajaran di sekolah selama tiga hari dan tiga hari selanjutnya mereka mengikuti pembelajaran "e-learning system" di rumah. Intinya siswa ke sekolah hanya melakukan konsultasi kepada guru tentang masalah-masalah pembelajaran. Dengan pembelajaran daring pada masa Covid-19 ini Kabupaten Tangerang tinggal melaksanakan perencanaan yang telah ada sebelumnya.

Secara keseluruhan proses pembelajaran daring di SMPN 2 Sukamulya Kabupaten Tangerang berjalan dengan baik meski memiliki beberapa kendala baik teknis maupun non teknis. Dinas pendidikan Kabupaten Tangerang memberikan tanggapan bahwa model pembelajaran daring berjalan dengan baik meski metode ini baru akan tetapi tenaga pengajar 
di Kabupaten Tangerang tidak begitu "kaget" sebab mereka sudah terbiasa dengan berbagai metode pengajaran, sedangkan menurut Kepala SMPN 2 Sukamulya metode daring ini berjalan dengan lancer meski diawal-awal guru mengalami beberapa kendala, sedangkan guru-guru/tenaga pengajar di SMPN 2 Sukamulya berpendapat bahwa metode pengajaran secara online (daring) yang diprakarsai oleh kementerian pendidikan dapat berjalan meski belum $100 \%$, sedangkan menurut orang tua peserta didik metode pembelajaran daring berjalan sekitar $80 \%$ sebab menurutnya metode pengajaran secara langsung (luring) tetap lebih baik daripada pembelajaran daring, mengingat berbagai aspek dalam proses pembelajaran saling berkaitan misalnya semangat/motivasi, kedisiplinan peserta didik berbeda jika dibandingkan antara pembelajaran daring dan luring/tatap muka secara langsung.

Pembelajaran daring di SMPN 2 Sukamulya masih kurang begitu efektif, sehingga hasil yang diharapkan masih jauh dari kesempurnaan. Meski demikian, metode pengajaran daring ini bisa dijadikan sebagai rujukan metode pengajaran baru yang bisa dilaksanakan oleh sekolah atau guru yang menginginkan menjalankan metode ini meski masa pandemi covid-19 sudah berakhir. Sehingga baik untuk pemerintah pusat maupun daerah perlu membuat beberapa regulasi untuk mengatur metode pengajaran daring, agar sekolah dan guru yang melaksanakan kegiatan ini berjalan dengan tertib dan teratur serta terprogram secara formal.

\section{E. KESIMPULAN}

Kebijakan pembelajaran daring di SMPN 2 Sukamulya Kabupaten Tangerang masih belum berjalan efektif. Faktor penghambat pembelajaran daring di SMPN 2 Sukamulya Kabupaten Tangerang yaitu masalah jaringan dan ketersediaan gadget yang tidak merata, motivasi peserta didik untuk mengikuti pembelajaran daring yang kurang baik, tingkat disiplin yang kurang baik, masih ada pada ruang kelas online di SMPN 2 Sukamulya, banyak peserta didik yang tidak focus pada materi yang diberikan/dipaparkan oleh guru, dan kurang meratanya ketersediaan sarana jaringan telekomunikasi.

Upaya yang digunakan oleh Pemerintah Kabupaten Tangerang dalam mengefektifkan pembelajaran Daring yaitu dengan menyediakan jaringan dan tambahan penguatan jaringan disetiap pelosok di Kabupaten Tangerang, memberikan bantuan khusus berupa gadget pendukung baik bagi guru/tenaga pendidik dan kependidikan, serta siswa yang kurang mampu, supervisi secara sistematis dan terprogram sehingga segala macam kendala yang ada dapat segera diketahui untuk dapat ditindaklanjut, dan bantuan langsung kuota internet maupun ketersediaan jaringan yang memadai.

\section{DAFTAR PUSTAKA}

Ahmadi, A., \& Supriyono, W. (2004). Psikologi Pendidikan. Jakarta: Rineka Cipta

Ameli, A., Hasanah, U., Rahman, H., \& Putra, A. M. (2020). Analisis keefektifan pembelajaran online di masa pandemi COVID-19. Mahaguru: Jurnal Pendidikan Guru Sekolah Dasar, 2(1), 28-37.

Arikunto, S. (2006). Prosedur Penelitian Suatu Pendekatan Praktek. Jakarta: Rineka Cipta. 
Dunn, W. N. (2003). Analisis Kebijakan Publik. Yogyakarta: Gadjah Mada University Press.

Hikmat, H., Hermawan, E., Aldim, A., \& Irwandi, I. (2020). Efektivitas pembelajaran daring selama masa pandemi Covid-19: Sebuah survey online. LP2M.

Ismail, S. M., \& Ichwan, M. N. (2008). Strategi Pembelajaran Agama Islam Berbasis PAIKEM (Pembelajaran Aktif, Inovatif, Kreatif, Efektif, dan Menyenangkan). RaSAIL Media Group.

Kyriacou, C. (2012). Effective Teaching Theori and Practice. Bandung: Nusa Media.

Mulyasa, E. (2005). Implementasi Kurikulum 2004. Bandung: Remaja Rosdakarya.

Mustaqim. (2009). Psikologi Pendidikan. Semarang: Fakultas Tarbiyah IAIN Walisongo.

Peraturan Bupati Tangerang Nomor 24 Tahun 2020 tentang Perubahan Atas Peraturan Bupati Nomor 20 Tahun 2020 tentang Pedoman PSBB dalam Percepatan Penanganan Corona Virus Disease 2019 (Covid-19).

Peraturan Pemerintah Nomor 38 Tahun 2007 tentang Pembagian Urusan Antara Pemerintah, Pemerintah Provinsi dan Pemerintah Kabupaten/Kota.

Riyana, C. (2020). Modul 1 Konsep Pembelajaran Online. Jakarta: Pustaka UT.

Rusman. (2010). Model-model Pembelajaran. Jakarta: Raja Grafindo Persada.

Saefuddin, A., \& Berdiati, E. (2014). Pembelajaran Efektif. Bandung: Remaja Rosdakarya.

Sari, D. P., \& Sutapa, P. (2020, August). Efektivitas Pembelajaran Jarak Jauh Dengan Daring Selama Pandemi Covid-19 Mata Pelajaran Pendidikan Jasmani Olahraga Dan Kesehatan (PJOK). In Seminar Nasional Olahraga (Vol. 2, No. 1).

Sudjana, N. (2005). Dasar-Dasar Proses Belajar Mengajar. Bandung: Sinar Baru Algensindo.

Surat Edaran Kepala Dinas Pendidikan Kabupaten Tangerang Nomor: 440/1211Disdik/III/2020 tentang Implementasi Kebijakan Pendidikan Dalam Masa Darurat Penyebaran Corona Virus Disease (Covid-19).

Surat Edaran Menteri Pendidikan dan Kebudayaan (Mendikbud) Republik Indonesia Nomor 4 Tahun 2020 tentang Pelaksanaan Pendidikan Dalam Masa Darurat Coronavirus Disease (Covid-19).

Undang-Undang Republik Indonesia Nomor 23 Tahun 2014 tentang Pemerintah Daerah. 